\title{
Effect of extreme temperature on egg development, larval and adult survival of Chordodes nobilii Camerano, 1901 (Gordiida, Nematomorpha)
}

\author{
Cecilia Luján Achiorno 1,2 , Lucrecia Ferrari ${ }^{3,4}$ and Cristina De Villalobos $1,4^{*}$ \\ ${ }^{1}$ Facultad de Ciencias Naturales y Museo Universidad Nacional de La Plata, Paseo del Bosque S/N, 1900 La Plata; \\ ${ }^{2}$ Consejo Nacional de Investigaciones Científicas y Técnicas Av. Rivadavia 1917 CP C1033AAJ Ciudad de Buenos Aires; \\ ${ }_{3}^{3}$ Programa de Ecofisiología Aplicada, Departamento de Ciencias Básicas, Universidad Nacional de Luján, Casilla de Correo 221, \\ B6700ZBA-Luján; ${ }^{4}$ Comisión de Investigaciones Científicas de la Provincia de Buenos Aires 526 e/10 y 11; Argentina
}

\begin{abstract}
On the basis of experimental studies we analyzed the effect of extreme temperatures on the aquatic free-living phases of the life cycle of Chordodes nobilii (Gordiida. Nematomorpha). Bioassays were performed with eggs, larvae, and adults. Eggs and larvae were exposed to $3^{\circ} \mathrm{C}$ below zero and $40.5^{\circ} \mathrm{C}$; adults were exposed to $3^{\circ} \mathrm{C}$ below zero and to $38.5^{\circ} \mathrm{C}$ and $40.5^{\circ} \mathrm{C}$. The results showed that egg development was inhibited in both tests. Exposed larvae showed a decrease in their infective capacity, which resulted almost null at $40.5^{\circ} \mathrm{C}$. Adults exposed to $38.5^{\circ} \mathrm{C}$ showed mortality $\leq 10 \%$. at $40.5^{\circ} \mathrm{C}$ the mortality was $100 \%$ and the adult's mortality at $3^{\circ} \mathrm{C}$ below zero was $89 \%$. Results indicate that free living stages of Chordodes nobilii are susceptible to extreme temperatures.
\end{abstract}

\section{Keywords}

Nematomorpha, Gordiida. Chordodes nobilii, life cycle, extreme temperatures

\section{Introduction}

Many abiotic factors affect directly and indirectly freshwater organism causing no visible detrimental effects (Huggins and Harp 1983. Mason and Hominick 1995), temperature is one of them. Seasonal changes in freshwater environments such as ponds and streams, can reach extreme limits. from complete freezing to very hot temperatures in summer. like in Sierra de la Ventana (Argentina), were adults of Chordodes nobilii (Gordiida) have been collected during all seasons, the absolute maximum and minimum temperatures varies between 38.2 $39.9^{\circ} \mathrm{C}$ (summer) and $7.7-9.8^{\circ} \mathrm{C}$ below zero (winter) (National Meteorological Services Information). These seasonal changes in temperature probably impacts on freshwater environments were free-life stages of Gordiida inhabit.

Although several studies have been developed on the complex life cycle of Nematomorpha over the past years (SchmidtRhaesa 2001. 2002; Bolek and Coggins 2002; Hanelt and Janovy 2003, 2004; De Villalobos et al. 2003; Zanca et al. 2007 ), the Gordiida is still a group that has received limited ecological or physiological study (Swanson 1982. Chandler 1985. Schmidt-Rhaesa 1997. Bolek and Coggins 2002). Tem- perature is a principal factor influencing egg development and survival of free stages in Gordiida (Camerano 1897; Dorier 1925, 1930: Thorne 1940; Baer 1951; Cappucci 1976; Whittaker and Barker 1983 and Zanca et al. 2007). Camerano (1897) and Dorier $(1925,1930)$ analyzed. with different results, the thermal tolerances in different species of Gordiida. Taking into account the scarce data about the tolerance of Gordiida to extreme temperatures, the purpose of the present paper is to report results of experiments conducted with eggs, larvae and adults of Chordodes nobilii subjected to extreme temperatures. Using the information obtained from this study we hope to predict periods where gordiids may be susceptible to temperature related with their reproduction and mortality.

\section{Materials and methods}

\section{Collection and maintenance of Chordodes nobilii}

Adults of Chordodes nobilii were collected in late summer from E1 Negro stream ( $\left.38^{\circ} 07^{\prime} 28^{\prime \prime} \mathrm{S}, 61^{\circ} 45^{\prime} 32^{\prime \prime} \mathrm{W}\right)$. Sierra de La Ventana. Argentina. The specimens were placed in $1000 \mathrm{ml}$ plastic containers with well aerated water. at room tempera- 
ture $\left(23 \pm 1^{\circ} \mathrm{C}\right)$. After copulation the females were separated in individual containers. Egg strings were collected from each mated pair and rinsed in 1:250 Clorox bleach solution. as described previously (Hanelt and Janovy 1999) and placed into $50 \mathrm{ml}$ plastic containers.

Bioassays were performed with eggs (mainly in blastula stage), larvae and adults. General bioassay conditions were selected based on preliminary trial (Achiorno et al. 2008).

\section{Temperature test}

Eggs: Twelve pieces of egg strings ( $3 \mathrm{~mm}$ in length each) from one of the females were stored in $12 \mathrm{ml}$ plastic containers with well aerated water and observed with light microscope until most of them reached the blastula stage. Two exposure tests were carried out: one at $3 \pm 1^{\circ} \mathrm{C}$ below zero and another at $40.5 \pm 11^{\circ} \mathrm{C}$. for 96 hours. Both tests included control groups maintained at room temperature $\left(23 \pm 1^{\circ} \mathrm{C}\right)$. All tests were carried out in triplicate.

After the exposure time of each test the egg strings were maintained at room temperature with weekly observations of each replica $(n=100$ eggs), during the following 30 days under light microscope (LM), in order to evaluate if the egg development was normal, retarded. interrupted or if the eggs were suffering some deterioration (e.g. collapse, wall rupture).

Larvae: Portions of egg strings from the selected female at room temperature $\left(23 \pm 1^{\circ} \mathrm{C}\right)$ were observed under LM during 20-25 days, until the larvae were completely developed (inside the egg shell as well as in hatched larvae). In order to determine the effect of extreme temperatures $\left(3 \pm 1^{\circ} \mathrm{C}\right.$ below zero and $40.5 \pm 11^{\circ} \mathrm{C}$ ) during 48 hours on Chordodes nobilii larvae, the same test protocols used for the egg strings was followed. In order to evaluate the survival of $C$. nobilii larvae. taking into account that larvae do not show constant movement, once the exposure time ends. the larvae are placed at control temperature $\left(23 \pm 1^{\circ} \mathrm{C}\right)$. After 24 hours, experimental infections with larvae of Aedes aegypti (Diptera) were performed. Plastic capsules of $3 \mathrm{~cm}$ diameter each one containing $12 \mathrm{ml}$ of well water, wheat germ as sediment and 30 larvae (L2 and L 3 instars) of $A$. aegypti were used for this analysis. After being exposed for $72 \mathrm{hrs}$. mosquito larvae were fixed in $70 \%$ ethanol and then dissected under LM to search for C. nobilii larvae in the body cavity. This procedure was followed for each replicate.

The survival of $C$. nobilii larvae was determined by evaluation of their infective capacity with the Infection Index Mean Abundance (IIMA), as the total number of C. nobilii larvae divided by the total number of host (A. aegypti larvae) observed (Bush et al. 1997). These bioassays were considered valid when IIMA in the control group was $\geq 2$.

Adults: Two tests were carried out, at $3 \pm 1{ }^{\circ} \mathrm{C}$ below zero and at $38.5 \pm 1^{\circ} \mathrm{C}$, during $96 \mathrm{hrs}$. The temperature chosen for the second test follows the results obtained by Dorier (1930) who observed that the movements of adults of Gordius aquaticus; Gordionus violaceus and Parachordodes gemmatus rapidly decreased when exposed at $37.5^{\circ} \mathrm{C}$.
In both tests, forty males of $C$. nobilii were placed in four $500 \mathrm{ml}$ glass containers each one with ten specimens. Two of the samples were taken as a control group and maintained at $23 \pm 1^{\circ} \mathrm{C}$.

In order to test the survival at $38.5^{\circ} \mathrm{C}$, adult specimens were observed four times, every $24 \mathrm{hrs}$. during 10-15 min. Viability was evaluated by their mobility and compared with the control groups. The adults that did not respond to mechanical stimulus were separated from the experimental units and placed at $23^{\circ} \mathrm{C}$ during $24 \mathrm{hrs}$. After this. the specimens that did not recover were considered dead to avoid confusion with sublethal effects.

As mortality in the specimens exposed during $96 \mathrm{hrs}$ at $38.5^{\circ} \mathrm{C}$ was $\leq 10 \%$, the survival specimens were exposed at $40.5 \pm 1^{\circ} \mathrm{C}$. during other $96 \mathrm{hrs}$ with daily observations to evaluate mobility.

In order to evaluate the survival of adults of $C$. nobilii exposed at $3^{\circ} \mathrm{C}$ below zero during $96 \mathrm{hrs}$, specimens were observed during 7 days post exposition at $23^{\circ} \mathrm{C}$ to determine whether they were recovering their normal activity (e.g.
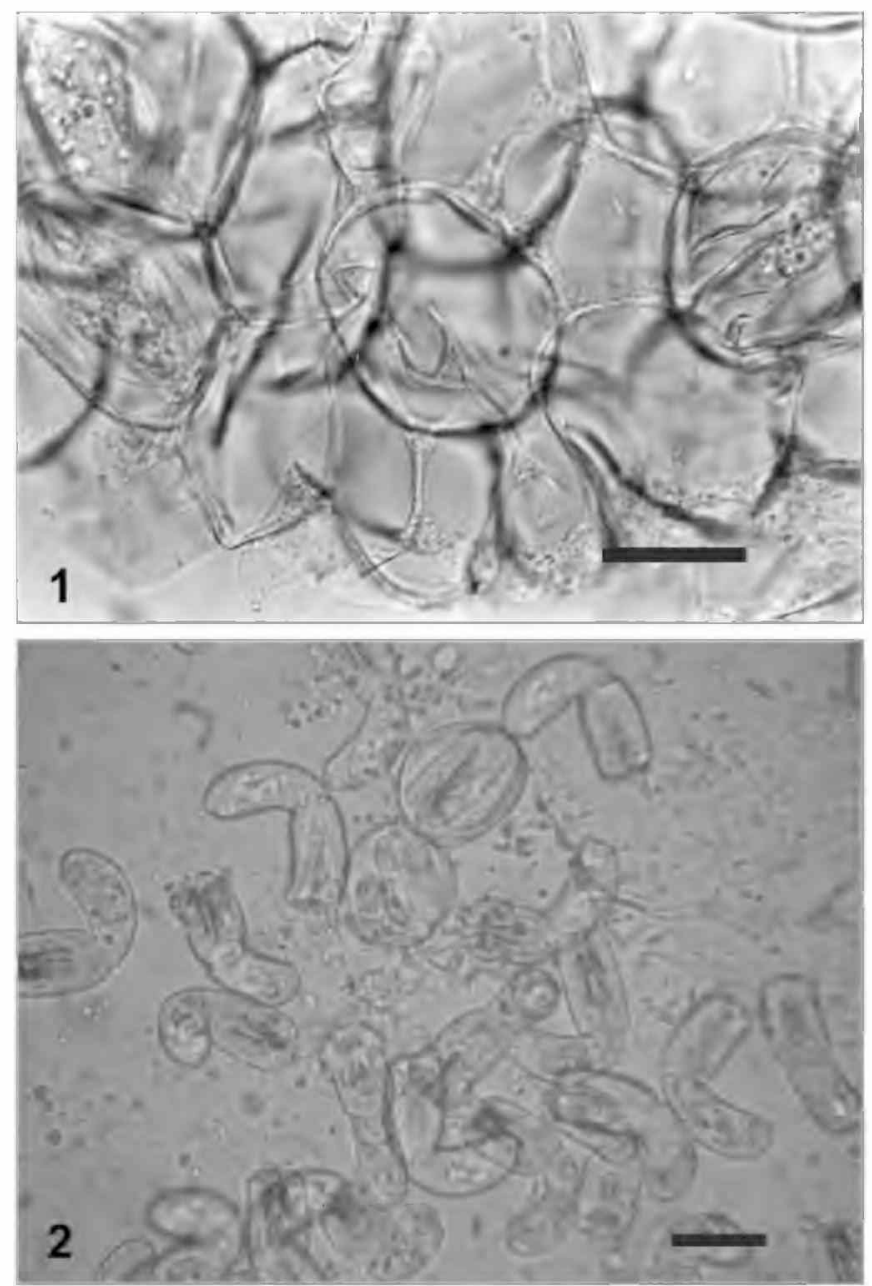

Figs 1 and 2. 1. Non viable embryos in one of the samples from exposed eggs ( 30 days post exposition). Scale bar $=15 \mu \mathrm{m}$. 2. Free living larvae and ready-to-hatch larvae within egg capsules in one of the samples from control eggs ( 30 days post exposition). Scale bar $=15 \mu \mathrm{m}$ 
swimming, rolling). General bioassay conditions were selected based on a preliminary trial.

\section{Data analysis}

The Shapiro-Wilk test and the Levene median test were used to assess normality and homogeneity of variance of data. respectively.

For the assays with larvae the Student's t-test. $p<0.05$ was used to check for significant differences between the control and treated group (Zar 1999). The null hypothesis (Ho) supposed that the IIMA media of the larvae exposed at $3^{\circ} \mathrm{C}$ below zero is equal to the IIMA media of the larvae of the control group.

Significant differences between the control and treated groups were determined for the tests with adults using oneway ANOVA with time as a covariable followed by Tukey's test after Ln transformation of the data (Zar 1999). The sig- nificance level was set at $\mathrm{p}<0.05$. Statistical analyses were performed using Infostat software.

\section{Results}

From the results obtained during the observations of the eggs strings post exposition (30 days), both treatments at $3^{\circ} \mathrm{C}$ below zero and at $40.5^{\circ} \mathrm{C}$ interrupted their embryonic development and damaged eggs have been observed (egg membrane rupture and embryo retraction) (Fig. 1). The control group continued the egg development normally with over $50 \%$ proportion of free larvae after 30 days (Fig. 2).

The bioassays carried out with larvae showed that in spite of their exposure at $3^{\circ} \mathrm{C}$ below zero during $48 \mathrm{hrs}$, the $C$. nobilii larvae could infect the 1 . aegypti larvae. although a statistically significant decrease was registered with respect to

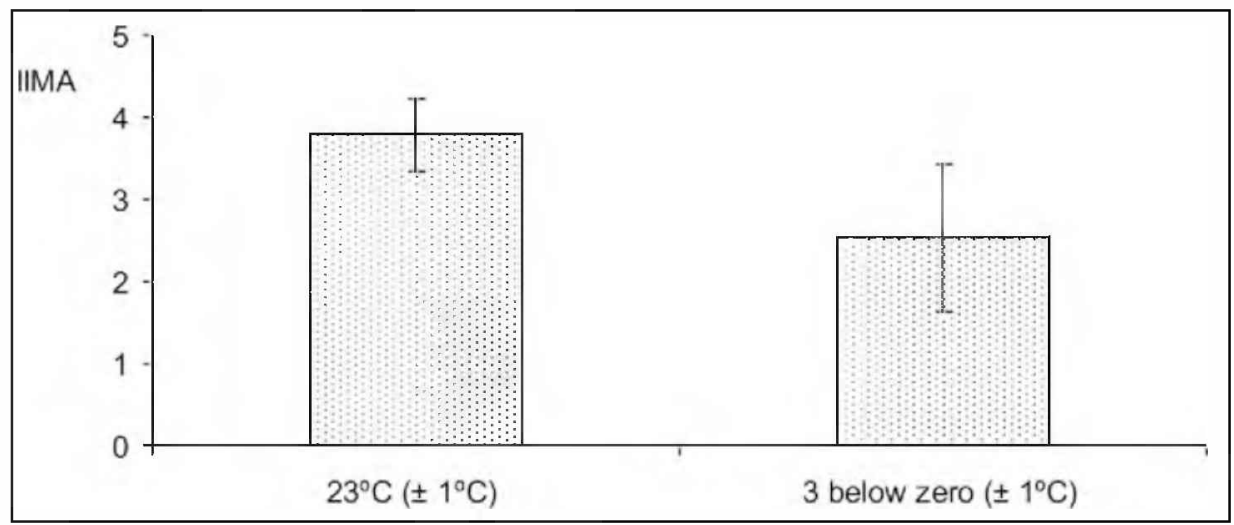

Fig. 3. Infection Index Mean Abundance (IIMA) \pm SD observed for the control and the $3^{\circ} \mathrm{C} \pm 1^{\circ} \mathrm{C}$ below zero in the larvae assays. Value expressed as arithmetic mean by treatment

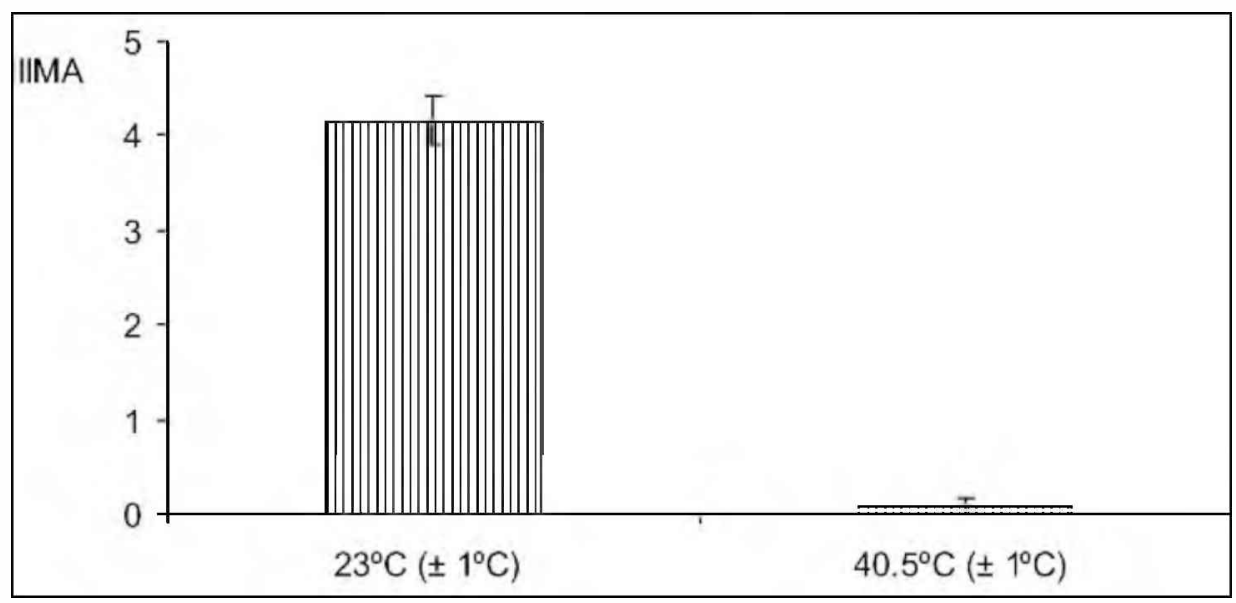

Fig. 4. Infection Index Mean Abundance (IIMA) $\pm \mathrm{SD}$ observed for the control and the $40^{\circ} \mathrm{C}\left( \pm 1^{\circ} \mathrm{C}\right)$ in the larvae assays. Value expressed as arithmetic mean by treatment 


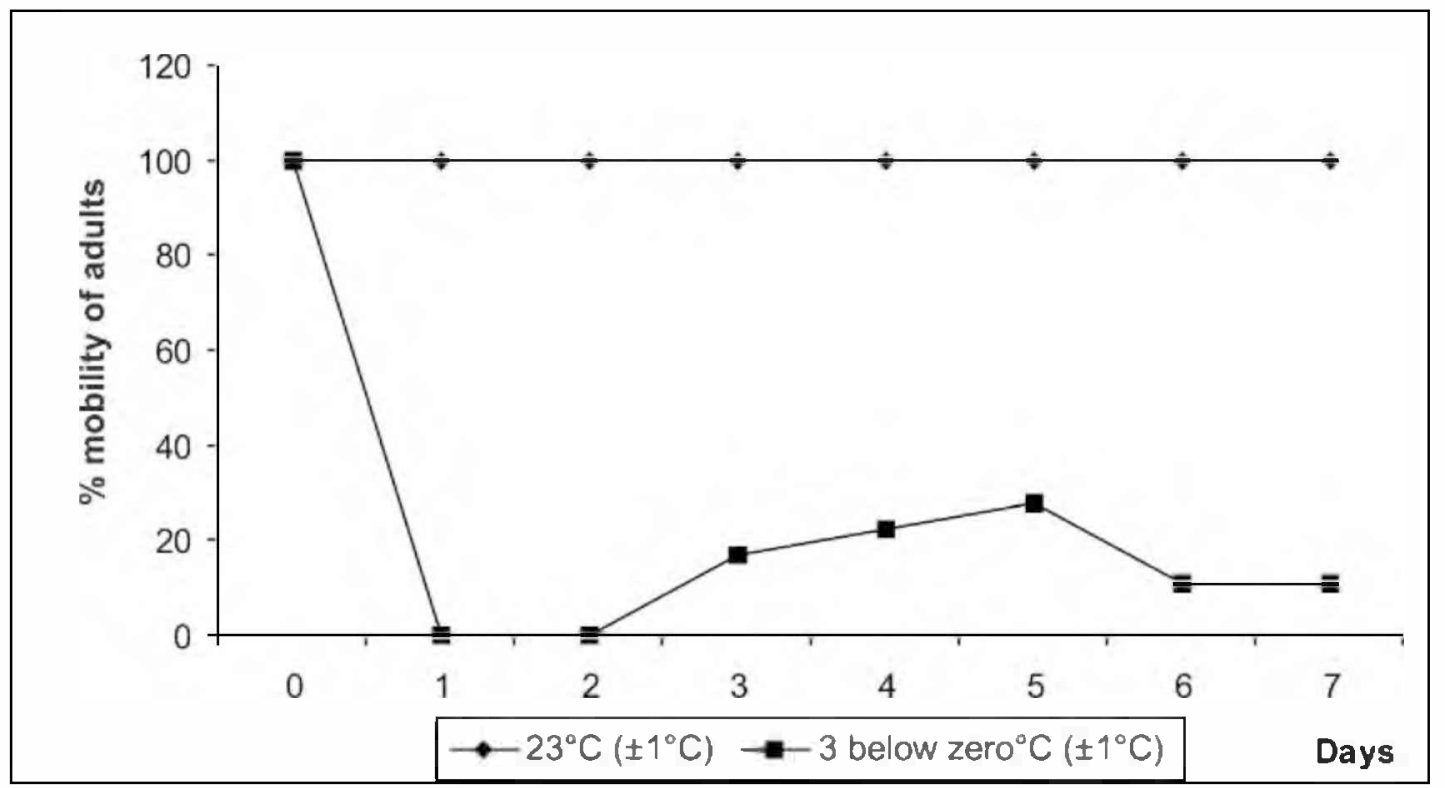

Fig. 5. Curve percentage of mobility in adults exposed to $3^{\circ} \mathrm{C}$ below zero $\left( \pm 1^{\circ} \mathrm{C}\right)$ and the control $23^{\circ} \mathrm{C}\left( \pm 1^{\circ} \mathrm{C}\right.$ ), for the day 0 (pre-exposure) and for days after exposure (from day 1 to day 7)

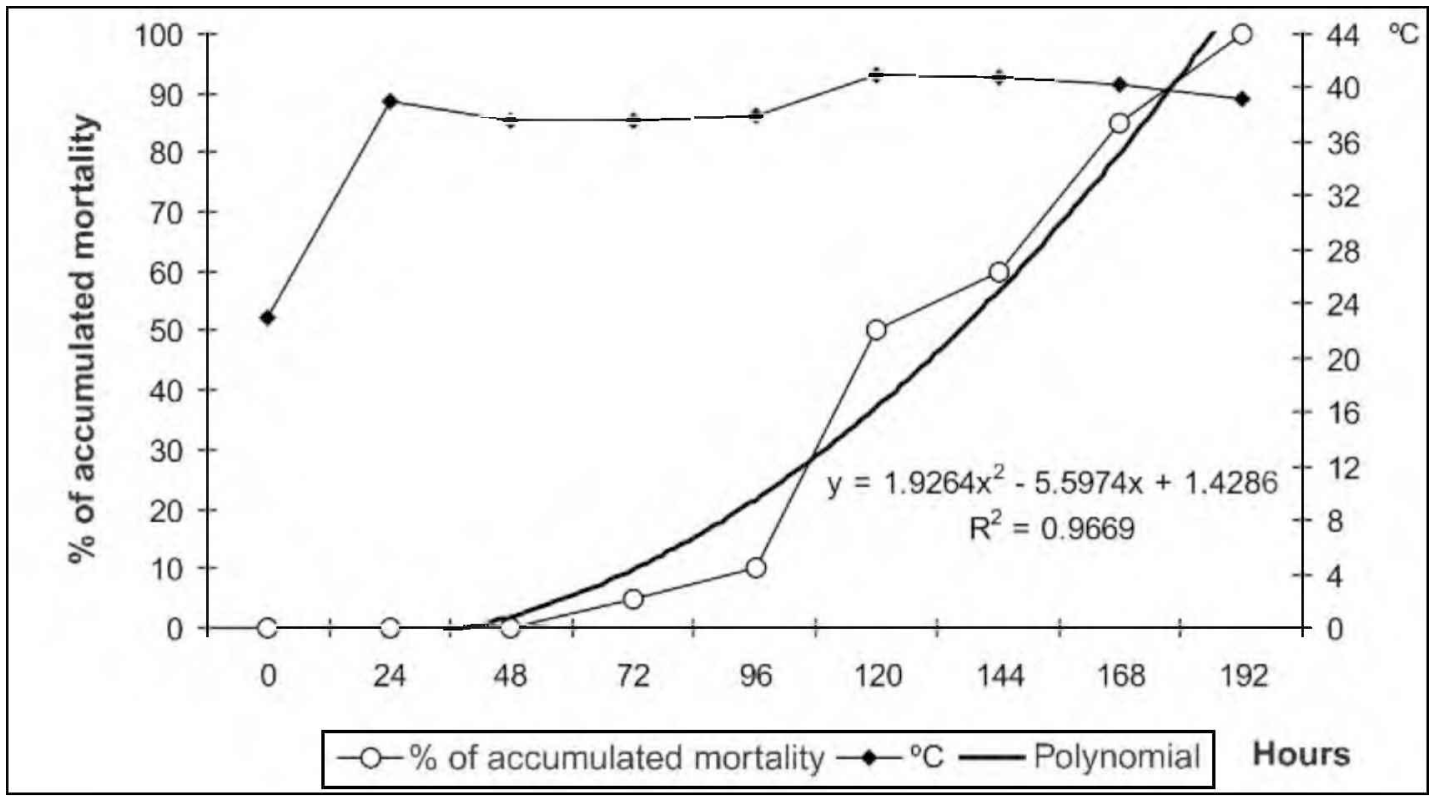

Fig. 6. Curve percentage of cumulative mortality for adults exposed to $38.5^{\circ} \mathrm{C}\left( \pm 1^{\circ} \mathrm{C}\right)$ and $40.5^{\circ} \mathrm{C}\left( \pm 1{ }^{\circ} \mathrm{C}\right)$, respect to exposure time (in hours)

the control group (statistical $\mathrm{t}_{0.05(2) .2}=4.53304148$ ) (Fig. 3). The larvae exposed at $40.5^{\circ} \mathrm{C}$ showed an important decrease in their infective capacity with a statistically significant difference (statistic $\mathrm{t}_{0.05(2) .2}=31.38$ ) (Fig. 4).

The experimental studies with adults showed that $28 \%$ of the specimens exposed to $3^{\circ} \mathrm{C}$ below zero recovered their mobility 120 hrs post exposition. At day 7 only $11 \%$ of the specimens continued with mobility (Fig. 5). The control group showed normal movements. In the adult's bioassays at $38.5^{\circ} \mathrm{C}$ during $96 \mathrm{hrs}$ the specimens were found entangled in a knot with no mobility, but after $10 \mathrm{~min}$ worms recovered their normal activity. The mortality was $10 \%$, with no significant differences with the control group. But when the temperature was increased in two grades $\left(40.5^{\circ} \mathrm{C}\right)$. after the first $24 \mathrm{hrs}$ an exponential increase of mortality of $50 \%$ could be observed. reaching $100 \%$ at the end of the exposure period ( $96 \mathrm{hrs}$ ) (Fig. 6). Median Lethal Temperature (TL50) occurs in the range between 38.5 and $40.5^{\circ} \mathrm{C}$. 


\section{Discussion}

The effect of low temperatures on the egg strings of C. nobilii was studied by Zanca et al. (2007) showing when maintained at $5^{\circ} \mathrm{C}$ they were capable of continuing their embryonic development. In our study we can prove for the first time that extreme temperature inhibits the embryonic development.

Dorier (1930) studied the effect of different temperatures on the mobility of Gordius aquaticus larvae. He observed that $50 \%$ of the larvae exposed at $37^{\circ} \mathrm{C}$ showed no mobility after two and a half hours and after thirty hours all of them were dead. Our observations of $C$. nobilii larvae exposed at $40.5^{\circ} \mathrm{C}$ showed that only a few larvae survived and could enter the corporal cavity of $A$. aegypti larvae.

There are previous reports on the effect of low temperatures on the survival of larvae. Hanel and Janovy (1999) found that Gordius robustus larvae stored in tap water at $4{ }^{\circ} \mathrm{C}$ remained viable for 5 months. Zanca et al. (2007) reported that C. nobilii larvae were able to survive 6 months at $5^{\circ} \mathrm{C}$. Our results are the first to evaluate the effect of the freezing temperature on C. nobilii larvae and allow us to determine that the larvae exposed at $3^{\circ} \mathrm{C}$ below zero can survive and are able to complete their life cycle in contrast to those exposed at $40.5^{\circ} \mathrm{C}$.

The analyses carried out by Camerano (1897) on the thermal tolerances of adults in Gordius aquaticus, Parachordodes tolosanus and P. pustulosus showed that the mobility of the specimens decreases at $25^{\circ} \mathrm{C}$. stops at $39^{\circ} \mathrm{C}$, and at $44^{\circ} \mathrm{C}-$ $46^{\circ} \mathrm{C}$ they die. Dorier (1930) considers that the adults of Gordionus violaceus exposed at $37^{\circ} \mathrm{C}$ die after three days. while G. aquaticus and Parachordodes gemmatus die within 7-9 days.

In the adults of $C$. nobilii we observed that for the conditions tested the tolerance to temperatures exceeding $38.5^{\circ} \mathrm{C}$ significantly increased mortality of adults.

Our results indicate that aquatic free-living phases of the life cycle of Chordodes nobilii are susceptible to extreme temperatures, especially at $40.5^{\circ} \mathrm{C}$.

Acknowledgements. We would like to thank Dr. Juan Garcia from the Parasites and Vectors Research Center (CEPAVE) for his kind donation of Aedes aegypti eggs. Many thanks also to two anonymous reviewers for constructive comments on the manuscript.

\section{References}

Achiorno C., de Villalobos C., Ferrari L. 2008. Toxicity of the herbicide glyphosate to Chordodes nobilii (Gordiida, Nematomorpha). Chemosphere, 71, 1816-1822. DOI: 10.1016/j. chemosphere.2008.02.001.

Baer J.G. 1951. Gordiacea. Ecology of animal parasites. University Illinois Press Urbana, 43-45.

Bolek M., Coggins J. 2002. Seasonal occurrence, morphology, and observation on the life history of Gordius difficilis (Nematomorpha: Gordioidea) from southeastern Wisconsin, United States. Journal of Parasitology, 88, 287-294. DOI: 10.1645/ 0022-3395
Bush A.O., Lafferty K.D., Lotz J.M., Shostak A.W. 1997. Parasitology meets ecology on its own terms: Margolis et al. revisited. Journal of Parasitologv, 83, 576-583. DOI: $10.2307 / 32$ 84227.

Camerano L. 1897. Monografia dei gordii. Memoria Reale Accademia Scienze Torino, 47, 339-419.

Cappucci D.T. 1976. The biology of Gordius robustus Leidy with a host list and summary of the public health importance of the Gordioidea. PhD Thesis, University of California, San Francisco, California, $240 \mathrm{pp}$.

Chandler C.M. 1985. Horsehair worms (Nematomorpha, Gordioidea) from Tennessee, with a review of taxonomy and distribution in the United States. Journal of the Tennessee Academy of Science, 60, 59-62.

De Villalobos C., Rumi A., Núñez V., Schmidt-Rhaesa A., Zanca F. 2003. Paratenic hosts: larval survival strategy in Paragordius varius (Leidy, 1851) (Gordiida, Nematomorpha). Acta Parasitologica, 48, 98-102.

Dorier A. 1925. Sur la faculté d'enkystment dans l'eau de la larve du Gordius. Compte Rendu de l'Académie des Sciences, Paris 181, 1098-1099.

Dorier A. 1930. Recherches biologiques et systematiques sur les Gordiacés. Travaux du Laboratoire d'Hydrobiologie et de Pisciculture de l'Université de Grenoble, 22, 1-183.

Hanelt B., Janovy J., Jr. 1999. The life cycle of a horsehair worm, Gordius robustus (Gordioidea: Nematomorpha). Journal of Parasitology, 85, 139-141. DOI: 10.2307/3285720.

Hanelt B., Janovy J., Jr. 2003. Spanning the gap: identification of natural paratenic hosts of horsehair worms (Nematomorpha: Gordioidea) by experimental determination of paratenic host specificity. Invertebrate Biology, 122, 12-18. DOI: 10.1111/j. 1744-7410.2003.tb00068.x

Hanelt B., Janovy J., Jr. 2004. Life cycle and paratenesis of American gordiids (Nematomorpha: Gordiida). Journal of Parasitol ogy, 90, 240-244. DOI: 10.1645/GE-78R.

Huggins J.A., Harp G.L. 1983. Aquatic Macroinvertebrates of the Heatt Prairie Region Franklin Country Arkansas. Proceedings of the Arkansas Academy of Science, 37, 92-94.

Mason J.M., Hominick W.M. 1995. The effect of temperature on infection, development and reproduction of heterorhabditids. Journal of Helminthology, 69, 337-345.

Schmidt-Rhaesa A. 1997. (Eds. J. Schwoerbel and P. Zwick) Nematomorpha. Süßwasserfauna von Mitteleuropa. Vol. 4/4. Gustav Fischer Verlag, Stuttgart, Germany, 124 pp.

Schmidt-Rhaesa A. 2001. The life cycle of horsehair worms (Nematomorpha). Acta Parasitologica, 46, 151-158.

Schmidt-Rhaesa A. 2002. Australian species of Chordodes (Nematomorpha) with remarks on the genus and its life history. Journal of Natural History, 36, 1569-1588. DOI: 10.1080/00222 930110059664.

Swanson C.J. 1982. Nematomorpha. In: (Ed. S.P. Parker) Synopsis and Classification of Living Organisms. Vol. 1. McGraw-Hill, New York, 931-932.

Thorne G. 1940. The hairworm Gordius robustus Leidy as a parasite of the mormon cricket Anabrus simplex Haldeman. Journal of the Washington Academy of Sciences, 30, 219-231.

Whittaker F.H., Barker R.L. 1983. Some observations on the egg string of a nematomorph worm Paragordius sp. Transaction of the Kentucky Academy of Science, 44, 76-77.

Zanca F, de Villalobos C., Rumi A. 2007. Larval survival strategy during winter of Chordodes nobilii Camerano, 1901 (Gordiida Nematomorpha). Acta Parasitologica, 52, 382-385. DOI: $10.2478 / \mathrm{s} 11686-007-0055-7$.

Zar J.H. 1999. Biostatistical analysis. Fourth edition. Prentice Hall, Englewood Cliffs, New Jersey, 663 pp

(Accepted September 2, 2008) 